\title{
Leaders in Conversation: The Dialectic Model of Leadership Education in Plutarch's Lives
}

\author{
Brent Edwin Cusher \\ Department of Leadership and American Studies \\ Christopher Newport University
}

\begin{abstract}
In this essay, I explore the question of how best to leverage the benefits of dialogue for leadership education. The essay makes the case for studying the work of the ancient Greek historian Plutarch, who provides us with a unique kind of dialogue about leaders and leadership in his Lives. This text features biographical sketches of important leaders from the ancient Greek and Roman traditions that are intended by the author to be in conversation with one another. In this essay, I present a brief content analysis of two lives, Lycurgus of Sparta and Numa Pompilius of Rome, with the aim of clarifying the leadership themes contained therein and showing how students of leadership can benefit from the conversation between these two biographies facilitated by Plutarch. In general, Lives is a resource though which students can enter into a profitable dialogue about important historical examples, revealing truths about leadership that help students to grapple with vital questions.
\end{abstract}

\section{Introduction}

Dialogue has long served as an indispensible tool in education. Longstanding and systematic models hold that education cannot occur in the absence of robust dialogue (Kazepides, 2010). Reaching into the ancient past for the original and classic example of such a model, one sees Socrates touch the souls of his many students through conversation (Burbules \& Bruce, 2001, pp. 1102-1103; Kazepides, 2010, p. 90). This Socrates, whom readers encounter in the writings of Plato and Xenophon and whom one commentator has described as the very "patron saint of liberal education" (Marks, 2013), engages his students using a method known as dialectic. In this model of education, dialectic is a conversation in which two different points of view are expressed and subjected to rational scrutiny alongside one another, the purpose of which is to show the unreasonable or contrasting aspects of these perspectives as such, thereby showing the truth more clearly. Accordingly, the teacher has the greatest impact on students by means of dialogue, turning their souls, as it were, toward truth and fundamentally changing their lives for the good (Plato, 1991, pp. 193-99; see also Friedländer, 1958, pp. 154-170; Voegelin, 1957, pp. 13-14). This original model of dialectical education persists to the present day. Defending an idea of education that bears the clear stamp of Socrates, Orwin (2012) has remarked pithily that a "so-called education without live dialogue between teacher and student should excite no one."

These general introductory reflections have been concerned with the relationship between dialogue and liberal education. My aim is to show how this same dialectical paradigm can also 
pay rich dividends for those interested in leadership education. This is not to argue that leadership education and liberal education are naturally at odds with one another; several recent studies have persuasively shown their compatibility and even their co-dependency (Colvin, 2003, pp. 28-36; Riggio, 2013, p. 13; Wren, et al., 2009). Still, the connection between dialogue and leadership education is not as self-evident as it may seem. How, for instance, might dialectical conversation, which resides in the realm of speech, become translated into something useful for the process of leadership, which resides primarily in the realm of deed?

While research on leadership education seems historically to have treated dialogue only in passing, this question about its role in leadership education has more recently been approaching the forefront of research. Polelle (2007) refers to the figure of Socrates himself, arguing that the very process of dialectic was both a form of intellectual leadership and an instrument for educating students about how to be better judges of leadership. Socrates' conversations demonstrated to his followers, for instance, how to hold "leaders to higher standards" (p. 90; see also Harter, 2013, pp. 154-170; Wills, 1994, pp. 160-70). Others have taken a different approach, exploring the benefits of specific elements of dialogue. In his study of Maurice Merleau-Ponty's work, Harter (2012) has advocated that students of leadership become more acutely sensitive to different and frequently competing points of view. All "knowledge in leadership is knowledge from a point of view," and because of this fact, Harter maintains that the practical wisdom useful for leading requires understanding one's own point of view, considering those of others, and "blending" them together (pp. 169-70) - a process for which dialogue is tailor made (see also Hiller, deChurch, Murase, \& Doty, 2011). Harter's reading of Merleau-Ponty deftly draws on the original Socratic model of dialectic and presents a modification of it, where synthesizing points of view is the essence of a good leadership education.

Building off of this research, I aim to show that sustained attention to a different authorPlutarch — and his work can enrich this growing scholarly conversation about dialogue, providing unique and useful guidance on the question of the importance of dialogue for leadership education. Who, first of all, was Plutarch? He was an ancient Greek historian, biographer, and moral thinker who lived from the years 46 to 120 A.D. (see Duff, 1999, pp. 1-2; Lamberton, 2001, pp. 1-59). Plutarch is justly famous for writing a text that has come to be known as Parallel Lives, also commonly referred to as Lives, in which he has paired histories of notable men from the Greek tradition with comparable counterparts from the Roman tradition. Among other purposes served, Lives is a true classic of the study of leadership. In 1870, the transcendentalist thinker and essayist Ralph Waldo Emerson famously referred to Plutarch's Lives as "a bible for heroes" (1870, p. xxi). Much more recently, Cronin (1984) has remarked in reference to an ideal leadership education that "[s]tudents of leadership can learn widely from reading biographies about both the best and the worst leaders. Plutarch's Lives would be a great place to start" (p. 34).

Engagement with the writings of Plutarch is, therefore, not new in the world of leadership research (see also Bass, 2008, pp. 4-5; Genovese, 2013, p. 2; Kellerman, 1986, pp. 350-351, 374375). What I endeavor to show, however, is that the guidance provided by Plutarch on the link between dialogue and leadership education is uniquely enriching, insofar as his work provides readers access to a special kind of dialogue, i.e., the dialectical comparison of leader biographies. 
Plutarch's intention with Lives is for his treatment of these biographical pairs to be in conversation with one another, providing even an explicit comparison for many of his pairings. In placing lives of comparable leaders who represent the different points of view of the Greek and Roman contexts in dialogue with one another (Tatum, 2010, p. 18), Plutarch's work embodies the dialectical ideal in its aim of ushering the truth about leadership into the light of day. Furthermore, the text allows educators of leadership to set their own students in dialogue with the ancient past, for engagement with leadership examples that can seem radically different from the context of our own time forces students to clarify their own leadership experiences. In short, Plutarch's Lives is a resource though which students can enter into a rich dialogue about important historical examples, revealing truths about leadership that help students to grapple with vital questions.

I demonstrate these benefits of Plutarch's work for leadership education by presenting a short content analysis of one of his most memorable pairs, Lycurgus and Numa Pompilius. My intention is to provide guidance and suggestions for leadership educators who may be interested in incorporating these dialectical elements of Plutarch's work into their teaching, whether those courses cover the historical treatment of leadership, leadership theory, or leadership ethics. The essay concludes with a set of summary reflections on the benefits of Plutarch's unique kind of dialogue for leadership education.

\section{Plutarch's Dialogue in Action, Part One: Lycurgus, Numa Pompilius, and Leadership}

There are at least two important themes in the study of leadership that link together Plutarch's biographies of Lycurgus and Numa Pompilius. First, the two figures were defined by their great successes in foundational lawgiving, a project of leadership that establishes basic norms for a community and inspires a sense of togetherness - of peoplehood-among the members of the group (Plutarch, 2001, p. 102). Gardner (1995) sets forth a typology of leadership that includes, in part, leaders who give new direction to large institutions such as political regimes or religious orders (p. 12). This formal classification seems to capture perfectly well what Plutarch means by the notion of foundational lawgiving.

Lycurgus comes from the Greek tradition and was the chief reformer of the laws of Sparta (Plutarch, 2001, p. 56). Numa lived at the beginning of Roman history and was a king and, in essence, the founder of the Roman religion, the all-important framer who ordered the religious rites for the city (Plutarch, 2001, pp. 87-94). Both leaders have been seen by the tradition to be instrumental in founding their respective regimes. In other words, if no Lycurgus, then no Sparta, and if no Numa, then no Rome. That the two figures were among the most consequential and skillful lawgivers the world has ever known is the opinion of many distinguished commentators. This, for instance, is the explicit assessment of the philosophers Niccolò Machiavelli (1996, p. 35) and Jean-Jacques Rousseau (2005, pp. 172-73), the latter of which refers to these two in the same breath as Moses.

Second, Plutarch's histories of these two lawgivers provide key insight into the conditions for the longevity of institutions, a subject that ought to be considered integral to leadership studies. To be sure, it seems only natural to think of leadership not in terms of 
longevity, but in terms of an active orientation toward change. Process-based definitions, for instance, such as that proposed by Northouse (2012, p. 5), conceive of leadership as an influence attempt on a group of individuals for the sake of moving the group progressively closer to a common objective. Research on leader behavior has even come to include a change-centered model, according to which leaders act by adapting to the environment and promoting major changes in the processes of the organization (Ekvall \& Arvonen, 1991, pp. 17-26; Yukl, 2010, pp. 68-70). However, when changes have been made and the desired outcome has been actualized, it seems just as natural to say that the resulting outcome ought to be preserved. And preserve these two lawgivers did.

Plutarch indicates that "the city of [Sparta] continued the chief city of all Greece for the space of five hundred years, in strict observance of Lycurgus' laws; in all which time there was no manner of alteration made, during the reign of fourteen kings..." (2001, p. 79; emphasis supplied). As we slowly approach the 250 year mark of the United States Constitution and consider how the leaders of the founding generation set the nation on its path, it is remarkable to reflect on the endurance of the Spartan regime. Regarding Numa and his successes, one might profitably make reference to the celebrated nickname of Rome, i.e. "the eternal city." It should be noted that the laws of Lycurgus enjoyed a more stable resilience and permanence than those of Numa. Plutarch explains that Lycurgus was more effective in accomplishing this particular objective. Indeed, for Plutarch this may be the key subject brought to light through his analysis and comparison of these two lawgivers.

\section{Plutarch's Dialogue in Action, Part Two: Causes of Success}

The primary question to which an analysis of these two histories gives rise is the following: As leaders, how were Lycurgus and Numa responsible for the longevity of their laws? Given that the institutions founded by these lawgivers lasted far longer than their lives did, it would be worthwhile to know Plutarch's thoughts on the cause of such remarkable endurance. Moreover, if Plutarch explains that Lycurgus was comparatively more successful than his Roman counterpart, then why was he more successful?

There are two factors broadly discussed in Lives that account for the extraordinary success of the laws of Lycurgus and Numa: the virtuous character of the lawgivers, on the one hand, and the nature of the reforms each lawgiver sought to bring to his people, on the other. In sum, Plutarch locates the causes for resilience somehow in the traits of the leaders, including virtues both moral and intellectual; and in the specific plans that were deemed necessary to bring about change to the societies of Sparta and Rome.

\section{Traits of Character}

For "Plutarch, the chief object of the biographer was to reveal his subject's character" through a careful examination of his deeds (Duff, 1999, p. 5). Therefore, Plutarch is a useful resource for seeing the influence of character traits on the process of leadership, and the Lycurgus/Numa pairing does not disappoint in this regard.

We learn at least three important things about the character of Lycurgus in Plutarch's biography of the Spartan lawgiver. First, we see an innate sense for justice or morality; hence, Lycurgus 
may be recognized for putting the interest of others ahead of himself. We see this throughout the life: for instance, Lycurgus leaves the office of Spartan king voluntarily, laying down his official power to exercise leadership in other ways. One scandalous story illustrates the point. After his brother the king has died, his sister-in-law the queen proposes that she and Lycurgus slaughter her newborn baby boy and then rule Sparta together. Lycurgus agrees to the plan, but then promptly tricks the queen into letting him tend to the child, and in a dramatic flourish holds the baby up proclaiming him the king (Plutarch, 2001, pp. 54-55). Second, Plutarch (2001) explains that the private virtues of Lycurgus were irreproachable, such as to make a very public impression on his followers. After a political enemy named Alcander assaults him and stabs out his eye, Lycurgus brings this man into his home and into the fold, as it were, converting him into a friend and supporter. The former enemy, we learn, "had the opportunity to observe in [Lycurgus], besides his gentleness and calmness of temper, an extraordinary sobriety and an indefatigable industry" (pp. 61-62). In other words, the impressive virtues of Lycurgus' soul are outwardly on display for his followers. Third, and perhaps more importantly, Lycurgus is an example of great wisdom and prudence. Plutarch (2001) asserts that it was this quality of wisdom that distinguished his leadership qualities from those he led, insofar as "in him alone was the true foundation of sovereignty to be seen, a nature made to rule, and a genius to gain obedience". It is this quality of genius that represents the chief characteristic mark of "one who leads beautifully" (p. 79).

Numa exhibits similar virtues of character, even if in slightly different ways. We learn that Numa accepts a leadership role less for the benefit he will accrue and more for the good it can do for the city of Rome. Upon being elected to the kingship of Rome, he first of all "banished all luxury and softness from his own house" (Plutarch, 2001, p. 83). Numa's energies were directed not toward his own aggrandizement but rather toward the welfare of his people. Second, he was well known by citizens and strangers alike to be "an incorruptible judge and counselor, [and] in private [he] devoted himself not to amusement or lucre, but to the worship of the immortal gods..." Numa was, in other words, of irreproachable virtues in his private life, and his fellow Romans were impressed by his character. Third, and finally, Numa was a supreme exemplar of intellectual virtue, much like Lycurgus is described. Plutarch tells us that he brought to the task of leadership a soul perfectly attuned to virtue and "subdued by discipline, a severe life, and the study of philosophy" (Plutarch, 2001, p. 83). One important consequence of his philosophic study was the ability to subject his basest passions to reason and judgment (Liebert, 2009), thereby tempering his soul for the demanding tasks of leadership.

In short, Plutarch makes an overt point in these texts to show that Lycurgus and Numa are noteworthy exemplars of virtue, of the best and most noble of what it means to be human. To be sure, this point is in line with Plutarch's general tendency as a biographer. As Duff (1999) has shown, Plutarch tends to praise the subjects of Lives more than he criticizes them (p. 56). Even so, it is a point that demands notice, for Plutarch forges a link between the virtues of Lycurgus and Numa, on the one hand, and their successes as leader, on the other. The author does not merely imply, rather he positively asserts that followers were freely willing to follow their lead because of the elevated qualities of their character. In the case of Lycurgus and Numa, their ethical traits counted for getting the citizens of Sparta and Rome to accept and to respect the institutions that these leaders had created. 
The attempt to interpret the successes of Lycurgus and Numa in terms of traits, however, leaves several important questions unanswered. For instance, would their extensive personal virtues affect the condition of the law's resilience after the death of the lawgiver and over time? This seems less than likely, especially because succeeding generations of Spartans and Romans would have had no personal acquaintance or experience with the two founders. Moreover, it is important to notice that there really is no significant difference between the character traits of Lycurgus and those of Numa. Plutarch (2001) explicitly identifies the quality of "moderation" as being equally shared by both leaders (p. 101), and this virtue of character seems to capture what is most significant about their character traits. On the question, then, of the primary cause of the different levels of resiliency between the two regimes, it seems unlikely that certain character traits would be of significant explanatory power.

\section{Reforms of Sparta and Rome}

What about the second factor explaining the longevity of the laws for Sparta and Rome? Plutarch remarks, first, that Lycurgus and Numa had opposite tasks to accomplish with respect to transforming their followers. Lycurgus took a chaotic and dissolute Spartan people and made them harsher of morals, eminently ordered, and more warlike. Numa, by contrast, took an extremely warlike Roman people and made them softer and more temperate. According to Plutarch's (2001) beautiful imagery: "as musicians tune their harps, so the one let down the highflown spirits of the people at Rome to a lower key, as the other screwed them up at Sparta to a higher note, when they were sunken low by dissoluteness and riot” (p. 102).

Plutarch explains that Lycurgus was known to have initiated many changes to the Spartan regime. The objective of this lawgiver, indeed, was nothing less than a wholesale reformation of Spartan politics and society. Lycurgus transformed the politics of Sparta by founding the senate, intending for it to be an intermediary buffer between the monarchy and the people. This reform was no unimportant thing, for Plutarch (2001) explains that the formation of the senate gave the government a "happy balance and temper" (p. 59). But Lycurgus seems also to have recognized that the political institutions of Sparta could not rest on improper social conditions. Accordingly, an enormous task of his was to reform Spartan society from the ground up, focusing in particular on socio-economic conditions. He persuaded the new senators to renounce their right to the landed property they had owned and then divided the lands evenly among the people.

Beyond merely redistributing wealth, Lycurgus set out to banish both luxury from the Spartan regime and the desire for luxury from the Spartan soul by means of three ingenious reforms. First, he banned the use of silver and gold and created a new currency for Sparta in the form of heavy iron, which was unwieldy and difficult to use. Nobody wanted anything to do with the new currency and, accordingly, Lycurgus successfully undercut the desire to spend money. Second, he outlawed all needless, superfluous arts, promoting in their place people devoted to making the "common, necessary things." Third, he created the institution of the common meal for which Sparta was famous. All men had to eat in common, at a common table, with common food, and women had their own common meals (Plutarch, 2001, pp. 59-63). Citing a quip by Epaminondas, a prominent statesman and general from the city of Thebes, Plutarch (2001) explains the great utility of such reforms by noting that "treason and a dinner like this do not keep company together" (p. 63). 
The key to all of Lycurgus' changes was a different reform, namely his backbreaking system of education in the ways of the regime instituted for all Spartans. Lycurgus established an eminently public scheme of education to be undertaken from cradle to grave, in which children were supervised and disciplined according to a strict schedule for meals, exercises, and sports (Plutarch, 2001, p. 64). The purpose of this institution was to take a band of relatively disparate and disorganized people and to lead them into the resilient ways of Sparta, so as to make them feel a sense of togetherness or community, as if all were one people. In other words, the institutions of public education were subordinate to Lycurgus' project of lawgiving, insofar as they were necessary for getting the Spartan people to accept his laws on the whole. Accomplishing this project successfully required an extraordinary amount of effort. Lycurgus' reform blended together a constant superintendence in education with an almost inhumane suppression of private goods in favor of the common good.

Plutarch tells us that Numa had a different project to undertake with his lawgiving, insofar as the key business he sought to accomplish was to define and to re-order the religious ceremonies and offices for the Romans. If he was lawgiver, then he was primarily a giver of the divine law, or a prophet (Lycurgus played the role of prophet too, insofar as his laws were always expressed as "Rhetras," or laws that were given by Apollo through the Oracle at Delphi. See Plutarch, 2001, pp. 63-64). According to myth, Numa was friendly with, and perhaps even wedded to, the cave nymph Egeria and is said to have spoken with none other than Jupiter about religious charms to make it rain (Plutarch, 2001, pp. 83-84). Plutarch himself interprets such stories as "laughable," yet cites them to show how important the deity was for the Romans and how clearly charismatic the personality of Numa would have appeared to his followers. Such stories show "the feelings which people...by force of habit, entertained toward the deity" (2001, p. 95). Numa established precise rules and regulations for sacrifices, processions, religious dances, the constitution of the priests and the office of Chief Priest, and oversaw the construction of the temple of Vesta. This framer judged that the sanctions of religion would be not just useful, but positively necessary "to mollify and bend to peace the presumptuous and stubborn spirits of this people," provided that they could be brought to fulfill religious obligations not "in a hurry," as it were, but when they had proper "time and leisure" to attend to them (Plutarch, 2001, p. 94). Religion, for Numa, had a civil purpose insofar as it rendered the Roman people more temperate and peaceful.

\section{Plutarch's Dialectic Method for Leadership Education}

This brief content analysis of Plutarch's histories of Lycurgus and Numa has put us in a good position to reflect on how Plutarch's dialectic method can pay dividends for leadership education. To be sure, the very content of these two biographies is concerned with matters that are central to the study of leadership. For this reason alone, Plutarch's work should be viewed as useful for helping students to understand important themes related to leadership, followership, and context. Further, Plutarch's Parallel Lives is uniquely worthy of a place in leadership education, however, because it provides a way of exploring the subject that embodies the spirit of dialectic education. The chief objective of this kind of education, as has been noted, is to come closer to the refined truth of things by setting different points of view alongside one another, comparing them and subjecting both to rational scrutiny. 
How precisely has this objective been accomplished in our short analysis of the lives of Lycurgus and Numa? According to Plutarch, the following two institutional changes in the cases of Sparta and Rome are largely responsible for the great resilience of the laws: an intensely public education in the way of the regime in Sparta and religious institutions in Rome. In both cases, the foundational lawgivers were eminently qualified by means of their wisdom and intellectual virtue - conceived of as traits of character- to see the utility of such institutions. Moreover, their respectable moral virtues, such as their other-regarding natures and their irreproachable private qualities, were helpful in getting followers to accept their leadership. Both Lycurgus and Numa recognized how the souls of their followers, in the present and hopefully in the future, would be molded in profound ways by means of the salutary effect of these institutions. For Plutarch, it seems that the ability to shape the souls of their people was the key to making their regimes last. Such measures were necessary for inspiring a stable degree of institutional commitment in their followers.

Still, Plutarch is just as clear that Lycurgus, by means of his plan for education, was more successful than Numa in the project of promoting resilience. He makes this argument in his explicit comparison of the two points of view which immediately follows the two lives. Plutarch, therefore, not only allows the reader to reflect on the examples of these two leaders in dialogue with one another. He also sets forth his own results of exploring the examples of Lycurgus and Numa through a dialectical lens.

Plutarch (2001) explains that both lawgivers approached their projects of leadership with the same "design and intent," to "bring their people to moderation and frugality" (p. 102). It is all the more striking that readers observe major differences between Sparta and Rome upon the departure of their leaders. "One benefit among many that Lycurgus obtained by his course," Plutarch argues, "was the permanence which it secured to its laws." After considering the Spartan and Roman points of view in dialogue with one another, Plutarch identifies the chief cause of the difference in the Spartan program of public education. "The obligation of oaths to preserve [the laws] would have availed but little, if he had not, by discipline and education, infused them into the children's characters, and imbued their whole early life with a love of his government" (p. 105). In other words, the project of foundational leadership was, for Lycurgus, far more successful due to his insight into the crucial significance of a great depth in education. Numa's reforms, by contrast, paid comparatively little attention to the education of children. Whereas Numa's leadership seems far more humane with respect to families and the raising of children - he did not require that children become almost public property (pp. 103-4) - the fruits of his leadership did not enjoy the same staying power as those of his counterpart in Sparta. The Roman people reverted back to their high flown tempers after Numa's death.

\section{Conclusion}

Readers of Plutarch's Parallel Lives - in particular, the life of Lycurgus as discussed in this essay-are compelled to confront examples of leadership that seem out of place today. Sometimes they seem radically out of place. Even so, such jarring examples from ancient Greece and Rome to which Plutarch's work grants us access serve as a kind of dialectical paradigm in themselves. Students of leadership in the present day can reflect on the significant 
differences between the ancient point of view on leadership and their own experiences, thereby clarifying their own experiences and discovering what may be timelessly true about leadership. Leadership educators can expect, therefore, to find Plutarch's Lives to be a valuable comparative tool for helping students reflect on their own engagement with the process of leadership.

There is, however, a more immediate use of Plutarch's Lives for an effective education in leadership, provided that we educators are sensitive to the dialectic character of this text. Despite the harshness of the regulations that readers must confront when thinking of the example of Sparta, Plutarch's use of this example is perfectly in line with the goals of dialogue, since it helps readers to see more clearly a resilient truth about leadership. Lest the dispositions of followers are shaped to be fundamentally committed to the community or organization the leader is establishing, that community or organization will tend toward ephemerality. Indeed, Plutarch's unique kind of dialogue, in which he sets the leadership of these two foundational lawgivers in relief against one another, is particularly useful for helping scholars think through the question of the basis of institutional commitment. It is, therefore, particularly useful also to leadership educators seeking to teach about the theme of institutional commitment. The relative shortcomings of Numa's Rome and the relative successes of Lycurgus' Sparta demonstrate powerfully and clearly the importance of a good education is for the long-term aims of leadership.

\section{References}

Bass, B. (2008). The Bass handbook of leadership: Theory, research, and managerial applications ( $4^{\text {th }} e d$.). New York, NY: Free Press.

Burbules, N. \& Bruce, B. (2001). Theory and research on teaching a dialogue. In V. Richardson (Ed.), Handbook of research on teaching (4th ed.) (pp. 1102-1121). Washington, DC: American Educational Research Association.

Colvin, R. (2003). Leadership studies and liberal education. Journal of Leadership Education, 2(2), 28-36. doi: 10.12806/V2/I2/AB1

Cronin, T. (1984). Thinking and learning about leadership. Presidential Studies Quarterly, 14(1), 22-34.

Duff, T. (1999). Plutarch's Lives: Exploring virtue and vice. Oxford, UK: Clarendon Press.

Ekvall, G., \& Arvonen, J. (1991). Change-centered leadership: An extension of the threedimensional model. Scandinavian Journal of Management, 7(1), 17-26. doi: 10.1016/0956-5221(91)90024-U

Emerson, R.W. (1870). Introduction. In W.W. Goodwin (Ed.), Plutarch's Morals, (pp. ix-xxiv). London: Sampson, Low.

Friedländer, P. (1958). Plato: An introduction. Princeton, NJ: Princeton University Press. 
Gardner, H. (1995). Leading minds: An anatomy of leadership. New York, NY: Basic Books.

Genovese, M. (2013). Building tomorrow's leaders today: On becoming a polymath leader. New York, NY: Routledge.

Harter, N. (2012). Point of view: Leadership studies from different perspectives. Journal of Leadership Education, 11(2), 158-75. doi: 10.12806/V11/I2/TF1

Harter, N. (2013). Socrates' mission against reproachable ignorance: Leaders who refuse to acknowledge their ignorance and instead suppress criticism. In S.L. Muhr \& J. Lemmergaard (Eds.), Critical perspectives on leadership: Emotion, toxicity, and dysfunction (pp. 151-170). New York, NY: Edward Elgar.

Hiller, N., deChurch, L., Murase, T., \& Doty, D. (2011). Searching for outcomes of leadership: A 25-year review. Journal of Management, 37, 1137-1177. doi: $10.1177 / 0149206310393520$

Kazepides, T. (2010). Education as dialogue: Its prerequisites and its enemies. Montreal,QC: McGill-Queen's University Press.

Kellerman, B. (1986). Political leadership: A source book. Pittsburgh, PA: University of Pittsburgh Press.

Lamberton, R. (2001). Plutarch. New Haven, CT: Yale University Press.

Liebert, H. (2009). Plutarch's critique of Plato's best regime. History of Political Thought, 30(2), 251-71.

Machiavelli, N. (1996). Discourses on Livy (H. Mansfield \& N. Tarcov, Eds.). Chicago, IL: University of Chicago Press.

Marks, J. (2013). Socrates at the center. Inside Higher Ed. Retrieved December 23, 2013 from http://www.insidehighered.com/views/2013/04/18/liberal-education-and-civic-educationneed-not-go-together-essay.

Northouse, P. (2012). Leadership: Theory and practice. New York, NY: Sage.

Orwin, C. (2012). There's no online substitute for a real university classroom. Globe \& Mail. Retrieved December 27, 2013 from http://www.theglobeandmail.com/globedebate/theres-no-online-substitute-for-a-real-university-classroom/article4487214/.

Plato (1991). The Republic of Plato (A. Bloom, Ed.). New York, NY: Basic Books.

Plutarch (2001). Plutarch's Lives (A.H. Clough, Ed.). New York, NY: The Modern Library. 
Polelle, M.R. (2007). Leadership: Fifty great leaders and the worlds they made. Westport, CT: Greenwood.

Riggio, R. (2013). Advancing the discipline of leadership studies. Journal of Leadership Education, 12(3), 10-14. doi: 10.12806/V12/I3/C2

Rousseau, J.-J. (2005). The plan for perpetual peace, On the government of Poland, and other writings on history and politics (C. Kelly, Ed.). Hanover, N.H.: Dartmouth College Press.

Tatum, W. (2010). Why parallel lives? In Noreen Humble (Ed.), Plutarch's Lives: Parallelism and purpose (pp. 1-22). Swansea, UK: The Classical Press of Wales.

Voegelin, E. (1957). Plato. Baton Rouge, LA: Louisiana State University Press.

Wills, G. (1994). Certain trumpets: The nature of leadership. New York, NY: Simon and Schuster.

Wren, J., Riggio, R., Genovese, M. (Eds.) (2009). Leadership and the liberal Arts: Achieving the promise of a liberal education. New York, NY: Palgrave Macmillan.

Yukl, G. (2010). Leadership in organizations (7th ed.). Upper Saddle River, NJ: Prentice Hall.

\section{Author Biography}

Brent Edwin Cusher is an Assistant Professor of Leadership Studies in the Department of Leadership and American Studies at Christopher Newport University in Newport News, Virginia. His B.A. and Ph.D. degrees, both in political science with a concentration in political philosophy, are from Carleton College and the University of Toronto, respectively. Professor Cusher has held teaching positions at Carleton College, Rhodes College, the University of Alaska-Anchorage, and Christopher Newport University. 